Article

\title{
The Problem of Schelling as a Transition Thinker
}

\section{Virgilio A. Rivas}

\begin{abstract}
In the literature of German Idealism, the agreement on Schelling as an intermediate thinker between Kant and Hegel is a wellguarded scholarship. This essay will recast this agreement within the contemporary reception of Schelling, notably by Slavoj Žižek. But despite Žižek's important contribution to Schelling studies, his Hegelian reading of Schelling via psychoanalysis does little to resolve the problem of whether Schelling is a transition thinker or systematizer in his own right. In recent years, this problem is renewed by focusing on Schelling's significant leverage over his major rivals in terms of the centrality of Nature in his works. Iain Hamilton Grant's Philosophies of Nature After Schelling is by far the most crucial undertaking in this respect, enabling recent scholarship to reexamine Schelling's naturephilosophy in light of our current ecological predicament. But a key element is absent in Grant's naturalistic treatment. This element is the aesthetic which occupies a central role in Schelling's Naturphilosophie.
\end{abstract}

Keywords: aesthetics, Naturphilosophie, negative reason, positive philosophy

\section{The Intermediate Character of Schelling}

Tn Slavoj Žižek's description of the true legacy of F.W.J. Schelling (17751854), ${ }^{1}$ not only does German Idealism stand in need of urgent correction, despite Schelling himself-or because of him from being widely treated as a linear movement in Western intellectual history, which, over the course of centuries continues to exert huge influence on post-Enlightenment thinking, to a portrayal of its inner history as a shadowy spiritual double of the ideals of Enlightenment which Hegel, for instance, proposed to realize in historical consciousness.

${ }^{1}$ Slavoj Žižek, The Indivisible Remainder: On Schelling and Related Matters (London and New York: Verso, 2007).

(c) 2017 Virgilio A. Rivas

https://www.kritike.org/journal/issue 21/rivas december2017.pdf

ISSN 1908-7330

(cc) BY-NC-ND 
Žižek's salient reading of Schelling offers a nuanced approach in understanding the issue between the two erstwhile collaborators: one cannot understand Hegel, arguably the epitome of German Idealism, without inserting Schelling into the equation. What eludes the self-mediation in Hegel, Schelling identifies as the gap or the scission that escapes selfaffirmation at the same time that it makes affirmative presence possible. As Žižek remarks, "the subject can assert its self-presence only against the background of an obscure, dense, impenetrable Grund which withdrawsinto-itself the moment it is illuminated by the light of Reason." 2 But alongside this contrived collaboration of Schelling and Hegel, Žižek also in effect, reintroduces the problematic of 'Schelling' as a 'transition' thinker, "located in the break between two epochs."3 As Žižek elaborates, "[one] foot still within the universe of speculative Idealism whose theme is the immanent selfdeployment of the eternal Absolute; his other foot already encroaching into the post-Hegelian universe of finitude-contingency-temporality." 4

The problematic of Schelling as an intermediate thinker has been a familiar line of inquiry and contestation in late $20^{\text {th }}$ century accounts of the German Idealist tradition and its Romantic equal (but also anxious collaborators). Among them, Dieter Henrich's, Frederick Beiser's, and Manfred Frank's are household staples. ${ }^{5}$ But their expositions leave more questions (previously unacknowledged notwithstanding) than settle the matter for all its worth, especially in regard to the question of the transitional character of many of Schelling's interventions that traverse the idealist and romantic poles of German intellectual culture at the time. It was Hegel who initiated this problematic which generally expresses the "view that each philosophical position from Kant through [him] is like a step in a staircase that we ascend as we leave previous steps behind." 6 This technically makes Kant, Fichte, and Schelling a necessary turning point for the completion of Kant's intellectual work in Hegel's oeuvre. Against this background, Henrich,

${ }^{2}$ Ibid., 6

3 Žižek identifies the Weltarter drafts (1811-1815) as the most representative work of Schelling that articulates this transition. See Slavoj Žižek and F.W.J. Schelling, The Abyss of Freedom/Ages of the World: An essay by Slavoj Žižek with the text of Schelling's Die Weltarter (second draft 1813) in English translation by Judith Norman (Ann Arbor: The University of Michigan Press, 2004); see also F.W.J Schelling, The Ages of the World (Fragment): From the handwritten remains, third version (c. 1815), trans. by Jason M. Wirth (New York: State University of New York Press, 2000).

4 Žižek, The Indivisible Remainder, 7.

${ }^{5}$ See Frederick Beiser, German Idealism: The Struggle Against Subjectivism, 1781-1801 (Cambridge, Massachusetts, London and England: 2002; Manfred Frank, The Philosophical Foundations of Early German Romanticism, trans. by Elizabeth Millán-Zaibert (Albany, New York: State University of New York, 2004); and, Dieter Henrich, Between Kant and Hegel: Lectures on German Idealism, ed. by David S. Pacini (Cambridge, Massachusetts, London and England: Harvard University Press, 2003).

${ }^{6}$ See Henrich, Between Kant and Hegel, 9. 


\section{SCHELLING AS A TRANSITION THINKER}

for instance, proposed an interpretation of the late writings of Fichte, Schelling, and also of Hegel, where at that time, the late works were yet to be explored. More so, if one were to retrace the inspirational source of these works, "it was not yet possible to understand the basic implications of Kant's position." 7 Hence, the critical elaboration of the late works at the time of Hegel would properly expose the contingency of Hegel's own claims.

The importance of the late works, especially Schelling's, raises critical challenge not only to Hegel's highly influential self-appointment but also to other attempts, mostly by Hegelians to identify him as an initiator, an agent provocateur, so to speak, of a dangerous liaison between Nazi ideology and "anti-Enlightenment ambitions." 8 In his lecture on the German Romantics, Frank, for instance, rejects Lukács's criticism of Schelling for the latter's alleged advocacy of the conservative underpinnings of anti-rationalist thought that spread across the famous romantic interlude (in the poetically inclined writings of Goethe, Novalis, Schlegel, etc.). This negative criticism of Schelling's apparent anti-democratic leanings, intimated by his otherwise definitive position in relation to the Enlightenment, has become, as of late, a subject of revisiting, among others, Schelling's 'Stuttgart Seminars, ${ }^{9}$ notably by Habermas, wherein the romantic connection to authoritarian or statist ideology is rebuffed in favor of a genuine romantic Schelling who harbors a 'concealed' form of anarchistic ideals. ${ }^{10}$ In the 'Stuttgart Seminars,' Schelling favors the abolition of the state, arguing that humanity must "ensure that the state will progressively divest itself of the blind force that governs it, and to transfigure this force into intelligence." 11 Inasmuch as Schelling would certainly hold a view of reality in which reason indecisively oscillates, rather than freezes to a static end - such as the State - thereby making him "a sworn enemy of all ideology,"12 Lukács, a Hegelian Marxist, would dismiss

${ }^{7}$ Ibid. See also, Beiser, German Idealism: The Struggle Against Subjectivism, vii.

${ }^{8}$ Elizabeth Millán-Zaibert contends that this is based on a "misconception of early German Romanticism" in which Schelling immersed himself. See Elizabeth Millán-Zaibert, Friedrich Schlegel and the Emergence of Romantic Philosophy (New York: State University of New York Press, 2007), 14.

${ }^{9}$ See F.W.J. Schelling, Idealism and the Endgame of Theory: Three Essays by Schelling, trans. by Thomas Pfau (Albany: State University of New York Press, 1994), 195.

${ }^{10}$ See Jürgen Habermas, "Dialectical Idealism in Transition to Materialism: Schelling's Idea of a Contraction of God and its Consequences for a Philosophy of History," trans. by Nick Midgley and Judith Norman, in The New Schelling, ed. by Judith Norman and Alistair Welchman (London and New York: Continuum, 2004), 46.

${ }^{11}$ As quoted in Habermas, "Dialectical Idealism in Transition to Materialism," 46. See exact Schelling's text in Schelling, Idealism and the Endgame of Theory, 195.

${ }^{12}$ See Jason M. Wirth, Conspiracy of Life: Meditations of Schelling and His Time (Albany, New York: State University of New York, 2003), 239, n. 4. Wirth draws from Hannah Arendt the rhetorical context of this description of Schelling. See Hanna Arendt, The Origins of Totalitarianism (San Diego and New York: Harcourt, 1976), 469. See also Tyler Tritten, Beyond Presence: The Late F. W. Schelling's Criticism of Metaphysics (Boston and Berlin: William de Gruyter, 2012), 342.

(c) 2017 Virgilio A. Rivas

https://www.kritike.org/journal/issue 21/rivas december2017.pdf

ISSN 1908-7330

(c) $)$ BY-NC-ND 
Schelling as an enemy of reason that places him in unwarranted proximity with the conservative, otherwise barren romanticism of the party ideologues of the third Reich. ${ }^{13}$

In this vein, the inadvertent malice of Schelling's proverbial influence on Heidegger adds up to the historical confluence of conservative ideals and Nazi romanticism. Heidegger's relation to Schelling, nonetheless, is not an easy setup to begin with. His Nazi episode was, without a doubt, out of tune with Schelling. Meanwhile, Heidegger's famous description of Schelling as a remarkable thinker, but whose "judgment still stands under Hegel's shadow," 14 proves to be an oblique compliment which tends to ignore Schelling's true place in German Idealism. As a consequence, this blocks his reception, not least in the English-speaking world. ${ }^{15}$ As to the matter of 'receiving' Schelling according to his own terms, which I am more inclined to attach to the enduring complexity of his Naturphilosophie, ${ }^{16}$ the question of the real importance of Schelling, both in the internal history of German Idealism, the Romantics, as well in post-Hegelian philosophy, still remains obscured by the continuing influence of Hegel in much of critical theory today, and not least by Heidegger as the undisputed post-Husserlian figure behind contemporary phenomenological disputations.

Markus Gabriel, in his work on transcendental ontology, situates this nexus between Schelling and Heidegger within the context of transforming the "traditional conception of Being."17 Gabriel acknowledges Schelling's radical attempt, following Leibniz, ${ }^{18}$ to pursue the question of being to its never before expounded trajectory since the dawn of reason. In Heidegger's formulation, this engendered the so-called destructive retrieval of Being. ${ }^{19} \mathrm{In}$ the background of this hermeneutical connection (Schelling and Heidegger)-though Gabriel hardly mentions this despite his parallel

${ }^{13}$ Millán-Zaibert, Friedrich Schlegel, 14.

14 See Martin Heidegger, Schelling's Treatise on The Essence of Human Freedom, trans. by Joan Stambaugh (Athens, Ohio, London: Ohio University Press, 1985), 13.

${ }^{15}$ See Andrew Bowie, Schelling and Modern European Philosophy: An Introduction (London and New York: Routledge, 1993), 11. See also Beiser, German Idealism: The Struggle Against Subjectivism, 465.

${ }^{16}$ A more theoretically engaging work, such as Iain Hamilton Grant's Philosophies of Nature After Schelling, will be my principal informant along this troublesome trajectory. See Iain Hamilton Grant, Philosophies of Nature After Schelling (London: Continuum, 2006).

17 See Markus Gabriel, "Unprethinkable Being and Event: The Concept of Being in Late Schelling and Late Heidegger," in Transcendental Ontology: Essays in German Idealism (London and New York: Continuum, 2011), 61.

${ }^{18} \mathrm{Ibid}$. This point is also raised by Tritten in Beyond Presence, 5.

19 "By taking the question of Being as our clue, we are to destroy the traditional concept of ancient ontology until we arrive at those primordial experiences in which we achieved our first ways of determining the ways of Being." Martin Heidegger, Being and Time, trans. by John Macquarrie and Edward Robinson (New York: Harper \& Row, Publishers, Inc., 1962), 44. 


\section{SCHELLING AS A TRANSITION THINKER}

treatment of negative reason or negative philosophy in the same section in which he expounds on the Schelling-Heidegger nexus-is Schelling's announcement of positive philosophy, which represents the mature phase of his thinking, forging a counterpoint to the negativity of reason. In hindsight, Žižek conceives of the crucial emergence of positive philosophy as the outcome of Schelling's attempt to configure God as the 'unity of freedom and necessary existence' within a mythical narrative or theosophical chronicle, but could only become possible "at the price of splitting philosophy into 'positive' and 'negative.'" 20 As a theosophical narrative, the unity of God and existence is conceived independently of metaphysics (both in its pre-critical, pre-inventoried frame inspired by Spinoza, and its critical cataloguing analytic informed by Kant). Žižek, here, elaborates that, "negative philosophy provides the a priori deduction of the notional necessity of what God and the universe are; however, this What-ness [Was-Sein] can never account for the fact that God and freedom are - it is the task of positive philosophy to function as a kind of 'transcendental empiricism', and to 'test' the truth of rational constructions in actual life. ${ }^{21}$

In his Munich Lectures, Schelling aims precisely at making negative philosophy 'happen' in terms of promoting a kind of transcendent thinking, which he describes as a thinking that through its decision, "goes beyond the scope of the present reality." 22 Transcendent thinking is a free act in contrast to "the a priori operations of negative philosophy [occurring] in an unchanging network of pure thought, and thus do not 'happen'." 23 "To 'test' the truth of rational construction in actual life," 24 , Schelling leans, as an initial step, toward the supposedly inventoried reason of Kant, but only to the extent in which the limits of reason provide an opening into crossing the threshold of existence, whence commences the next step, away from pure thought and back into the primordial starting point, namely, the free act of existence, or simply, freedom. Here, freedom, as Schelling conceived it, is non-reflective. ${ }^{25}$

20 Žižek, The Indivisible Remainder, 39.

${ }^{21}$ Ibid.

${ }^{22}$ See Bruce Matthews, Translator's Introduction to F.W. J. Schelling, The Grounding of Positive Philosophy: The Berlin Lectures (Albany, New York: State University of New York, 2007), 41. The short English translation of the quoted passage above was lifted from Matthews's translation of the German edition of the Munich Lectures. See also F.W.J Schelling, Grundlegung der Positiven Philosophie. Münchener Vorselung WS 1832/33 and SS 1833, ed. Horst Fuhrmans (Turin: Bottega D' Erasmo, 1972).

${ }^{23}$ Ibid., 42. See also, Schelling, Grundlegung der Positiven Philosophie. Münchener Vorselung, 101.

24 Žižek, The Indivisible Remainder, 39.

${ }^{25}$ Evidently influenced by Fichte, Schelling recast the self-positing I of Fichte, originally as an act rather than as reflection, into a kind of productive intuition. Fichte says of intuition as follows: "What acting is, can only be intuited, not evolved from concepts or communicated

(c) 2017 Virgilio A. Rivas

https://www.kritike.org/journal/issue 21/rivas december2017.pdf

ISSN 1908-7330

(cc) BY-NC-ND 
But also as non-reflective, it is a pure act. As Schelling emphasized in an early essay, freedom as such is "the beginning and end of all philosophy." 26 Philosophy has its sole origin in a non-reflective act which presupposes, in Schelling, a kind of necessary existence that precedes philosophical reason, and which in fact "stops reason dead in its tracks, initiating a discontinuous transition through which [it] is pushed out of its predictable orbit of reflection." 27 Freedom calls for the necessity of the extra-logical nature of existence, one that can be freely created "beyond the scope of the present reality" 28 which is rationally determined. This enables Schelling, for instance, to recast mythology in the present which is heaved out of its 'predictable' determination, thus forging a "thinking that goes beyond itself into decision and action," a thinking that by all means is "transcendent." 29 Mythology therefore qualifies as an ahistorical or transcendent ground of the present, that is, as a free act that founds the present.

In Gabriel, however, Schelling's positive treatment of mythology constitutes two mutually interlocking problems for Heidegger who has already discerned in Schelling the onto-theological dilemma he could not escape. Gabriel elaborates this point as follows: "Schelling's philosophy," on the one hand, "seems to represent a possible escape from the tradition of ontotheological metaphysics," 30 associated with pre-critical metaphysics, accused by Kant of encouraging dogmatism and skepticism, but, "remains," on the other hand, "by Heidegger's lights one of onto-theology's central stations." 31 In the meantime, insofar as this prolific but intermittent thought production of Schelling can be recast in a Hegelian universe, one image that can be obtained here approximates that of the Egyptian Spirit entrapped in the Sphinx, "in itself a riddle," vague and indistinct in form, "half brute, half human." 32 This riddle can be transposed to the problematic of transition that

thereby..." See J.G. Fichte, The Science of Knowledge, trans. by Peter Heath and John Lachs (Cambridge: Cambridge University Press, 1982), 36.

${ }^{26}$ Schelling, "Of the I as the Principle of Philosophy, Or On the Unconditional in Human Knowledge," in The Unconditional in Human Knowledge: Four Early Essays (1794-1796), trans. by Fritz Marti (London: Associated University Press, 1980), 82.

${ }^{27}$ Matthews, Translator's Introduction, 41. For reference to the German edition on which Matthews translation was based, see also Schelling, Grundlegung der Positiven Philosophie: Münchener Vorselung, 101.

${ }^{28}$ Ibid.

${ }^{29} \mathrm{Ibid}$

${ }^{30}$ Gabriel, “Unprethinkable Being and Event: The Concept of Being in Late Schelling and Late Heidegger," 61.

${ }^{31}$ Ibid.

32 G.W.F Hegel, The Philosophy of History, trans. J. Sibree (Kitchener, Ontario: Batoche Books, 2001), 218.

(c) 2017 Virgilio A. Rivas

https://www.kritike.org/journal/issue 21/rivas december2017.pdf

ISSN 1908-7330

(cc) BY-NC-ND 


\section{SCHELLING AS A TRANSITION THINKER}

is supposed to be Schelling's place in the history of German thought. ${ }^{33}$ In Hegel's description, the Egyptian Spirit represents a riddle of the Spirit that "feels itself compressed." 34 The riddle may also suggest that by introducing a problem for the spirit to resolve through time, such as releasing the compressed spirit in Nature, which at present can "utter itself only in the sensuous mode," 35 the process of emancipation from the sensuous is an essential stage for the complete disclosure of what in essence is constricted therein, when finally "the Spirit has disclosed its existence." 36 But in Heidegger's interpretation, the problem of the Spirit, laid out in terms of the emancipation of what has been compressed in historical matter (nature and its avatars, for instance) in regard to the development of historical spirit until its culmination in Absolute Geist, constitutes Schelling's onto-theological dilemma. A dilemma is what "philosophy's questioning" is all about, in Heidegger's own terms, "always and in itself both onto-logical and theological" such that, as he elaborates, "the more originally it is both in one, the more truly it is philosophy." 37

But this Heideggerian conception of philosophy as a dilemma is far from Schelling's aim as to the general trajectory of his philosophical project. For instance, as the procedure of positive philosophy requires, the present must be unconditioned of its a priori grounding in terms of exposing the groundlessness of the a priori conditions of reason itself. This fairly amounts to a destruction of the dilemma intrinsic to negative reason. In this vein, Schelling offers an example of the outcome of unconditioning in terms of the conception of a mythological God which can be actualized in the nonreflective, free existence of humanity, that is, in a renewed present. In Schellingian terms, God exists as that which "groundlessly exists." 38 Here, Schelling provides the necessary completion of Kant: "[In] God it is precisely that, by virtue of that which groundlessly exists, that Kant calls the abyss of human reason - and what is this other than that before which reason stands motionless, by which reason is devoured, in the face of which it is momentarily nothing and capable of nothing." 39 By means of unconditioning, positive philosophy can now affirm necessary existence that is God as the prereflective unity of freedom and understanding. It is a unity that is never theo-

${ }^{33}$ Hegel opposes the apparent indiscernibility of Schelling's position to "the full body of articulated cognition" that he (Hegel) developed, thereby claiming that Schelling's position more or less is a type of "cognition naively reduced to vacuity." G. W. F. Hegel, Preface to Phenomenology of Spirit, trans. by A. V. Miller (New York: Oxford University Press, 1977), 9.

${ }^{34}$ Hegel, The Philosophy of History, 218.

${ }^{35} \mathrm{Ibid}$.

36 Ibid., 242.

${ }^{37}$ Heidegger, Schelling's Treatise on the Essence of Human Freedom, 51.

38 Schelling, The Grounding of Positive Philosophy, 205.

${ }^{39} \mathrm{Ibid}$.

(c) 2017 Virgilio A. Rivas

https://www.kritike.org/journal/issue 21/rivas december2017.pdf

ISSN 1908-7330

(c) BY-NC-ND 
logical in the sense that there is no separation between, say, existence and spirit which grounds theological discourse. However, it is also a unity inconceivable in negative reason which operates on the logical predication of subject-object distinction. Negative philosophy, in contrast, affirms existence but not as necessary; it affirms existence as a repeatable question (in Heidegger, at least, the question matures into the question of Being). In an early essay, Schelling argues: "[All] the failed attempts to answer this question share the mistake of attempting to explain conceptually what effectively precedes all concepts; they all betray the same incapacity of the spirit to tear itself away from discursive thinking and to ascend to the immediacy that exists within the spirit itself." 40

Schelling, here, is identifying where reason becomes impotent, that is, in the magic circle of conceptual immanence that he attributes to Kant, Fichte, and Hegel, but most strongly (about the time of the Berlin Lectures) to Hegel, vis-à-vis his notion of transcendent thinking. Any claim as to the completion of reason's dialectical journey in modernity is merely a mirror image of what reason cannot, in fact, accomplish, but posited as to appear that it has reached that stage. Žižek, for instance, falls into this game of appearance, so to speak, when he claims that Hegel completes the project that Kant initiated, with Schelling providing an unlikely assistance in terms of offering the only possible route to conclude the dialectical journey. According to Žižek, Schelling's "regression from pure philosophical idealism to premodern theosophical problematic" 41 presents a trajectory that is graspable only in Hegel's dialectical terms, as if its intelligibility does not hold in Schelling's own terms which appear to be lacking the necessary tool to carry out the task that ironically Schelling was the first to delineate. It is arguable that Schelling's regressive method indeed overtakes modernity as Žižek wants us to acknowledge. But as his argument goes, it sanctions the prevailing view that the problematic of Schelling is resolved into the matter of 'Schelling' as a mere transitional thinker.

\section{Overtaking Negative Reason}

Granting Žižek's formulation of Schelling's overcoming of modernity does reflect one of the key historical movements in German Idealism, it may be assumed that the 'modernity' that is said to have been overtaken by Schelling is the historical onto-theologically structured spirit, already deeply invested in the polarizing mesh of pre-critical and critical

40 See Matthews, Translator's Introduction, 221, n. 89. Matthews provides the reference for the passages above from the German edition of Schelling's works. See F.W.J. Schelling, Sämtliche Werke, ed. K. F. A. Schelling, First Division, Vol. 3 (Stuttgart, Cotta: 1856: 1861), 376.

${ }^{41}$ Žižek, The Indivisible Remainder, 8. 


\section{SCHELLING AS A TRANSITION THINKER}

thoughts, even before Hegel could begin the real work of completing the Enlightenment project. Supposedly, upon completion, modernity should be able to represent the project in a renewed light, in unambiguous form, shorn of the contradictions and antinomies of reason that once hindered its progress. Hence, a modernity that is already on the verge of an epoch-making transition. The co-existence, however, of two mutually conflicting assumptions regarding the direction of modernity would, as it were, serve as a stumbling block to Schelling's reception in contemporary period, insofar as his interventions in some of the most contested areas of intellectual concern in German philosophy refuse a reductionist treatment, as Gabriel and Žižek altogether attest in their respective appraisals of Schelling.

Gabriel's approach to Schelling, on the whole, however, differs from Žižek's, especially in light of the controversial 'freedom period' about which there is not enough consensus among scholars of Schelling agreeing on what is at stake in this critical phase of his intellectual journey. ${ }^{42}$ On the one hand, in view of Schelling's confrontation with the metaphysics of freedom, Gabriel creates a parallel consummation of philosophical projects between Schelling and Heidegger by critically imagining a united front against traditional metaphysics through their common historical conception of being. ${ }^{43}$ In both registers, the possibility of a future is established: tautegorical ${ }^{44}$ for Schelling; Ereignis for Heidegger. ${ }^{45}$ Gabriel elaborates: "[The] effort is aimed at making room for eschatological hope, precisely that which sets limit to philosophy the end or aim of philosophy that philosophy itself cannot determine from

${ }^{42}$ As Tritten points out, this is the focal point of Žižek's interpretation of Schelling. Tritten, Beyond Presence, 21.

${ }^{43}$ Gabriel, Transcendental Ontology, 61.

44 The notion of tautegory is meant in Schelling as a counter-point to the conceptual representations of myths as allegorical. As such, myths are interpreted according to their "accidental clothing" that conceals 'a prior meaning.' Tritten, Beyond Presence, 275. But Schelling contends that "mythology is thoroughly actual - that is, everything in it is thus to be understood as mythology expresses it, not as if something else were thought, something else said." F.W.J. Schelling, Historical-critical Introduction to the Philosophy of Mythology, trans. by Mason Richey and Markus Zisselsberger (Albany, New York: State University of New York Press, 2007), 136. Suffice it to say, mythology provides an opening into the future by 'overtaking' the 'scope of the present reality' through a tautegorical seizure of the categorical pretention of modern reason. The myth conceals nothing in the sense that it is in itself transcendent to subject-object distinction; instead it expresses an identity as subject-object, which, as early as in the System of Transcendental Idealism, Schelling describes as "a concept expressing fundamental duality in identity and vice versa" F.W. J. Schelling, System of Transcendental Idealism (1800) trans. by Peter Heath (Charlottesville: University Press of Virginia, 1978), 30.

45 Event signifies either "the taking place of difference [which is] the typical meaning of the expression," or, according to its commonplace meaning, refers to 'selfing' (Verselbstung). Ereignis is no less the coming-together of 'being and self'" which in Schelling can be referred to "as personality." Gabriel, Transcendental Ontology, 77. Both Ereignis and tautegory therefore take place in freedom (non-reflective for Schelling), but also in and through Dasein (Heidegger's equivalent of the Schellingian 'personality'), altogether as projecting-towards, as future.

(c) 2017 Virgilio A. Rivas

https://www.kritike.org/journal/issue 21/rivas december2017.pdf

ISSN 1908-7330

(c) $)$ BY-NC-ND 
within itself as its end or goal - an end that cannot be transcended by philosophizing itself." 46 On the other hand, Žižek dismantles the correlation between Schelling and Heidegger; instead, in an oblique but compelling sense, Kantianizes Schelling as a critical limit to Hegel-the former establishing a regulative limit to the precipitation of the Spirit in historical time. In this unusual complementariness, Žižek identifies the nexus between the two as constitutive of a "knot ... 'at which everything is decided'." 47 This is a stretch, as Žižek inaugurates in Schelling studies, that culminates in the clinical treatment of Schelling's concept of the indivisible remainder, in short, the unconscious or the 'lack' that occasions the subversive emergence of freedom. ${ }^{48}$ Here, the emergence of freedom is the proper Hegelian moment which formalizes by retrospective means the existence of the lack or void that Schelling introduces for the later work of subversion. Suffice it to say, there was 'freedom' in Schelling but unconscious; in Hegel it became a unity of conscious act in historical time in which the 'conscious' sublates the 'unconscious' and defines it (the unconscious) as immanent to the conscious work of history.

Notwithstanding his ingenious intervention in Schelling studies, Žižek's clinical treatment, however, raises two critical concerns. On the one hand, Schelling's Naturphilosophie is overlooked, if not entirely reduced to the moral and practical concerns of reason. If Naturphilosophie, as I will argue, consistently informs the whole stretch of Schelling's philosophical itinerary (from Spinoza, Kant, and Fichte, to the naturalists of his time who also became preoccupied with the central concerns of German romanticism as enunciated in the scientific and poetic writings of Goethe, Novalis, and Schlegel), then the matter of positive philosophy as a result of the transition (from the supposed early naturalistic leanings) cannot be addressed simply by first, stipulating a transition via the split between the 'positive' and 'negative,' and lastly, signifying this split as proof of the transition. Here, Žižek's Hegelian bias rears its ugly head. For Schelling to succeed in overtaking modernity as a result of the transition from negative to positive philosophy, the dialectical negativity of reason (exemplified by Hegel's system) must have already completed its project in historical consciousness. This amounts to saying that negative reason has exhausted its immanent history and is now ripe for the final Aufhebung courtesy of the self-correcting procedure that Schelling provides to Hegel's benefit. ${ }^{49}$

${ }^{46}$ Ibid., 96

47 Žižek, The Indivisible Remainder, 5.

${ }^{48}$ F.W.J. Schelling, Philosophical Investigations into the Essence of Human Freedom, trans. by Jeff Love and Johannes Schmidt (New York: State University of New York, 2006$), 29$.

49 In the Chapter on Being of the Science of Logic, Hegel describes sublation (often associated with the German aufheben) to mean that which aims to 'preserve' what has been 


\section{SCHELLING AS A TRANSITION THINKER}

This, of course, is not consistent with Schelling, à propos his critique of Hegel's concept of the Idea, whose claim to finality -its real breaking off to give way to the actual complement of the Idea, that is, Nature-cannot be the result of the self-realization of consciousness any more than it is of weariness or boredom:

[As] soon as it had to make a difficult step into reality the path of the dialectical movement broke off. A second hypothesis becomes necessary, namely, the Idea - one knows not why, unless to interrupt the boredom of its merely logical existence - allows its moments to fall apart, so that through them nature could arise. ${ }^{50}$

Insofar as negative philosophy cannot produce actual knowledge, as Schelling contends, ${ }^{51}$ dialectical reason can never complete its self-imposed task any more than it can even really begin in its own terms. This leads us to the second concern over Žižek's clinical approach, namely, the regressive procedure of overtaking modernity that he attributes to Schelling. But as Schelling himself defines the method of positive philosophy as "progressive Empiricism," any suggestion of seizure is certainly "not regressive, that is, does not proceed backwards from experience toward that which is above experience." 52 Rather, if there is backward movement, it occurs within negative reason, albeit, prompted by positive philosophy to pursue its groundless ground. By no means does this suggest that negative philosophy has already completed its trajectory, providing the occasion for positive philosophy to perform its task; rather, because negativity can never finish its self-imposed task until it is being intervened upon by something actual that lies outside its determination, it always requires the assistance of positive reason, but also always fails consistently to employ its leverage in the right terms.

The regressive seizure of modernity that Žižek describes of Schelling is in truth assigned to Hegel. The seizure through regression is actually a description meant for negative reason (in its highest deliberation in Hegel),

previously determined through mediation, hence, as Hegel adds, becomes "open to external influences." See G.W.F. Hegel, The Science of Logic, trans. by George Di Giovanni (New York: Cambridge University Press, 2010), 82. Hegel summarizes the meaning of sublation in one sentence: "That which is sublated is thus something at the same time preserved, something that has lost its immediacy but has not come to nothing for that." Ibid.

${ }^{50}$ See Matthews, Translator's Introduction, 59. For reference to the German edition, see Schelling, Sämtliche Werke, First Division, Vol. 10, 376.

51 Schelling, The Grounding of Positive Philosophy, 196.

52 See Matthews, Translator's Introduction, 71. For reference to the German edition, see Schelling, Sämtliche Werke, Second Division, Vol. 3, 130.

(c) 2017 Virgilio A. Rivas

https://www.kritike.org/journal/issue 21/rivas december2017.pdf

ISSN 1908-7330

(c) $)$ BY-NC-ND 
this time employing positive knowledge. But this in essence hijacks positive philosophy in order to deprive actuality of the efficacy reserved for the real experience of existence that negative reason "makes sure ... will never take place." 53 Žižek actually levels this critique at Kant but never to Hegel, which of course normalizes the standard narrative that Hegel completes Kant (through Schelling). In Žižek, positive philosophy is relegated to an instrumental status, which in the end, echoes the standard narrative about Schelling's intermediate place in German idealism.

\section{Aesthetic Relays in Naturephilosophy}

Inasmuch, however, as we agree that Schelling's Naturphilosophie is more than emblematic of his place in post-Kantian philosophy, which, incidentally, Iain H. Grant, in his treatment of Schelling's contemporaneity, has ushered in recent scholarship, ${ }^{54}$ I argue here that revisiting Schelling's naturephilosophy calls as much for a good aesthetic 'relay.' The 'relay' is reflective of the inner dynamics of Schelling's intellectual itinerary as of the coherence of his system. Schelling aims to frustrate regression to negative immanence, wherever such tendency appears, which denies existence by excising intellectual intuition from sensuous science, ${ }^{55}$ and hence, the attempt to restore intuition through aesthetics. Incidentally, Grant never raised this point as a permanent concern in Schelling, which is quite problematic, considering art complements, both in style and substance, Schelling's aim to ground everything in natural dynamics.

Devin Zane Shaw, in his thesis on the centrality of art in Schelling's philosophy, ${ }^{56}$ offers a good 'relay' in this respect. This is, by far, the most recent work detailing the scope of Schelling's aesthetic concern, following a much-focused exploration of the aesthetics of the young Schelling, ${ }^{57}$ published few years back before Shaw's dissertation. One key point, however, exposes a minor misconception of Schelling in Shaw's argument with which he differs from Grant's rather compelling naturalistic

53 Žižek, The Indivisible Remainder, 75.

${ }^{54}$ Grant, Philosophies of Nature After Schelling, 19.

${ }_{55}$ Schelling argues that "by denying every possible break into the objective ... there is no alternative ... other than to move to the opposite - to the all-destroying subject, which was now no longer the empirical subject of Descartes, but only the absolute subject, the transcendental I." F.W.J. Schelling, "Kant, Fichte, and the System of Transcendental Idealism," in On the History of Modern Philosophy, trans. by Andrew Bowie (New York: Cambridge University Press, 1994), 108.

56 Devin Zane Shaw, Freedom and Nature in Schelling's Philosophy of Art (Ph.D. Dissertation, Ontario: University of Ottawa, 2009). We are using the dissertation version here. For the published book version, see David Zane Shaw, Freedom and Nature in Schelling's Philosophy of Art (London and New York: Continuum, 2010).

${ }_{77}$ See Leonardo V. Distaso, The Paradox of Existence: Philosophy and Aesthetics in the Young Schelling (New York: Kluwer Academic Publishers, 2005). 


\section{SCHELLING AS A TRANSITION THINKER}

interpretation, notwithstanding its absence of aesthetics. In Freedom and Nature in Schelling's Philosophy of Art, Shaw argues that the aesthetic leverage is consistent with the earlier "subversion of Fichte's emphasis on practical reason." ${ }^{8} \mathrm{He}$ will be then led to conclude that later on, "Schelling abandons the philosophy of art" in favor of "a philosophy of freedom and his interest in the relationship between freedom, revelation and theology," 59 which, as the standard narrative goes, demonstrates a characteristic shift in Schelling, into what Shaw designates as "absolute idealism or identity-philosophy." 60 In relation to the view that aesthetics is being abandoned in favor of a philosophy of freedom, Jennifer Dobe, in her essay on Schelling's aesthetics, argues that Schelling understood freedom already as an ethical choice, which, if also understood to be pre-reflective or even extra-logical in the sense Schelling ascribes to existence, would naturally correlate with aesthetics, itself pre-cognitive. ${ }^{61}$ Thus, with this critical import of freedom in this socalled shift, Shaw in effect reemploys the misconception concerning the freedom-period, which, for instance, locates Schelling's philosophy in the break between the early or late Schelling, or, in Žižek's equation, between the 'negative' and the 'positive.' ${ }^{62}$ In Shaw, the turn to positive philosophy summons a relinquishing of aesthetics, thereby enhancing the standard account of the split.

Yet this period of positive philosophy (that Žižek refers to in the split between 'negative' and 'positive,' or Shaw in the shift to philosophy of freedom) is supposed to be that of the positive philosophy of mythology and religion, and not the positive philosophy of freedom. ${ }^{63}$ Tyler Tritten's important discussion of these points in Beyond Presence: The Late F.W.J. Schelling's Criticism of Metaphysics, will allow us to see that failure to comprehend the full extent of Schelling's intellectual itinerary can lead to serious misconceptions of the freedom-period that has ensnared, for instance, both Heidegger and Žižek, and many others exploring this period, into reformulating this pass into their own subjective interpretations of modernity. Heidegger assigned the name onto-theology, while Žižek, the regressive overtaking of historical reason.

Further complicating the problem of situating positive philosophy within the freedom-period, Leonardo Distaso, in The Paradox of Existence: Philosophy and Aesthetics in the Young Schelling, offers a contrasting leverage of

${ }^{58}$ Shaw, Freedom and Nature in Schelling's Philosophy of Art, 6.

${ }^{59}$ Ibid., 8.

${ }^{60}$ Ibid., v.

61 See Jennifer Dobe, "Beauty Reconsidered: freedom and virtue in Schelling's Aesthetics," in Interpreting Schelling: Critical Essays, ed. by Lara Ostaric (Cambridge: Cambridge University Press, 2014), 162.

62 Žižek, The Indivisible Remainder, 39.

${ }^{63}$ Tritten, Beyond Presence, 21, n. 26.

(c) 2017 Virgilio A. Rivas

https://www.kritike.org/journal/issue 21/rivas december2017.pdf

ISSN 1908-7330

(cc) BY-NC-ND 
aestheticism in Schelling: If Shaw abandons art in favor of his conception of the freedom-period as the positive philosophy of freedom, religion, and mythology, Distaso "[conceives] Aesthetics as a comprehensive philosophical theory and not a mere philosophy of art." 64 This is a more advanced speculation on the role of aesthetics in Schelling, and yet, a closer look at the programmatic execution of Distaso's work would reveal that much space is dedicated to establishing the primacy of aesthetics in relation to identity philosophy (in Shaw, identity-philosophy is supposed to be the cause of the falling out with aesthetics).

But as Grant reports, according to Schelling, the supposed identityphilosophy (the exact description is 'identity system') is a "designation" that he, "the author [Schelling] himself used just once."65 Schelling's own clarification, in "On the History of Modern Philosophy [and] the Philosophy of Mythology," demonstrates that the purpose of such designation is simply "to differentiate [his philosophy] from the Fichtean, which accords nature no autonomous being." 66 From the standpoint of Grant, the aesthetic connection to identity-philosophy will not authorize a conception of aesthetics as a 'comprehensive philosophical theory' (as in Distaso). Meanwhile, in regard to the critique of Fichte, which Shaw attributed to aesthetics, aesthetics cannot assume a function beyond the task assigned to it, that is, to differentiate Fichte's intellectual intuition from the productive intuition that Schelling described in as early as the System of Transcendental Idealism. ${ }^{67}$ Its function is to differentiate reflection and discursive thinking from that of expressing the nexus of thought (mind or consciousness) and nature from the standpoint of nature itself, that is to say, as productively imagined in thought. In this light, one can think with Schelling that the aesthetic function is to express the becoming visible of Nature as Mind, and the becoming invisible of Mind as Nature. ${ }^{68}$

${ }^{64}$ Distaso, Paradox of Existence, xiii.

${ }^{65}$ See Grant, Philosophies of Nature After Schelling, 4. See also, Schelling, Sämtliche Werke, 371.

${ }^{66}$ Ibid.

67 There are a number of precursors (which appeared in journals) to Shaw's line of inquiry here in terms of establishing the connection of Schelling's aesthetics announced in the System of Transcendental Idealism to the supposed function of identity philosophy as a challenge to Fichte's subjective idealism. These are: Antoon Braeckman, "From the Work of Art to Absolute Reason: Schelling's Journey Toward Absolute Idealism," in The Review of Metaphysics 57 (March 2004), 551-569; James Dodd, "Philosophy and Art in Schelling's System des transzendentalen Idealismus," in The Review of Metaphysics 52: 1(1998), 51-85; and Richard L. Velkley, "Realizing Nature in the Self: Schelling on Art and Intellectual Intuition in the System of Transcendental Idealism," in Figuring the Self, Subject, Absolute and Others in German Philosophy, ed. by David E. Klemm and Günter Zöller (Albany, New York: State University of New York Press, 1997), 149168. These works draw heavily from Dieter Jähnig, Schelling. Die Kunst in der Philosophie, 2 vols. (Pfüullingen: Neske, 1965); see Braeckman, "From the Work of Art to Absolute Reason: Schelling's Journey Toward Absolute Idealism," 553.

${ }^{68}$ Schelling, Ideas for a Philosophy of Nature, 41-42.

(c) 2017 Virgilio A. Rivas

https://www.kritike.org/journal/issue 21/rivas december2017.pdf

ISSN 1908-7330 


\section{SCHELLING AS A TRANSITION THINKER}

Already, the identity that this expression establishes is arrived through aesthetics, but not on account of so-called identity philosophy that, again, as Grant recounts, Schelling admitted was merely "a discovery of [his] youth." 69 This is not to say that identity itself is relinquished, as Grant clarifies, but rather marshalled in service of Naturphilosophie 'extended to the absolute.' Grant elaborates his position on this matter as follows:

Schelling defines the 'Positive Philosophy' that grounds both these projects [by which he means the Philosophy of Mythology and the Philosophy of Revelation] as an 'empiricism with regard to matter, only an aprioristic empiricism' ... One definition of naturephilosophy therefore runs as follows: "naturephilosophy is a naturalistic 'empiricism extended to the absolute'..$^{70}$

Grant, however, neglects the fact that in principle positive philosophy must be experienced aesthetically. Schelling himself insists that this type of philosophy is "directed immediately inwards, so as to reflect it in intellectual intuition," thus, the sense of which, apprehended in this intuitive production, reveals a precise structure, namely, aesthetic, which informs one of the chief declarations of the System of Transcendental Idealism that indeed aesthetics is "the true organon of philosophy." ${ }^{71}$ But Grant did not neglect aesthetics through an elaborate contraption to render it meaningless any more than the choice to sideline this important component is structurally directed by the aim of his project, not without a good sense of setting the order of priorities. Grant's aim is to dismantle the structures (overlaid by Kant's critical revolution, continuing up to Hegel) upon "the aesthetic and phenomenal access" to understanding "first nature."72 Kant himself was at pains to affirm nature beyond conceptual analogies. He was aware of the problem itself, and thus in the Groundwork of the Metaphysics of Morals proposed that the universality of moral ends ought to rest on a "composite idea of nature."73

This move constitutes Kant's definitive resolution to the antinomy of freedom and necessity. Without the postulate of dynamic interaction, such relation, as Wesley Philipps in "The Future of Speculation" observes, would lead to 'infinite insolubility' of subject or cosmos, each irreducible to the

\footnotetext{
${ }^{69}$ Grant, Philosophies of Nature After Schelling, 4.

${ }^{70} \mathrm{Ibid} ., 5$; bracket emphasis mine.

${ }^{71}$ Schelling, System of Transcendental Idealism, 14.

${ }^{72}$ Grant, Philosophies of Nature After Schelling, 70.

${ }^{73}$ See Wesley Philipps, "The Future of Speculation?" in Cosmos and History: The Journal of Natural and Social Philosophy 8:1 (2010), 294.
}

(c) 2017 Virgilio A. Rivas

https://www.kritike.org/journal/issue 21/rivas december2017.pdf

ISSN 1908-7330

(c) BY-NC-ND 
other; in the end, "subject and cosmos alike implode into nothingness." ${ }^{44}$ In this light, the dynamic relation between practical reason (or freedom) and nature would have decisively resolved the antinomies of reason. However, Kant's solution merely obtains a concept of nature that remains cyclical, thus, refractory to organic progress, not unlike the mechanistic view of reality. ${ }^{75} \mathrm{In}$ other words, as Philipps astutely remarks, "the generations cannot learn from their ancestors, nor pass on their moral goodness, since morality is the sole concern of individual, rational cognition." ${ }^{\prime 6}$ Without a historical task that goes beyond the 'scope of the present reality,' nothing can break the circle of immanence. ${ }^{77}$

In Schelling, the historical task must first assume the form of a reconstruction, starting with the pre-history of consciousness, hence, the nexus between aesthetics (as pre-cognitive actuality) and nature. For his part, Grant's approach to Schelling is to revive the problem of Kant peculiar to precritical metaphysics that Kant never transcended, thereby also renewing the question of the existence of nature or the unconditioned principle (of all that is - God or first cause). In this sense, Grant re-emboldens Schelling's critique of Kant by suspending the aesthetic concern in favor of the more urgent interest in those structures that Kant created, blocking access to nature (the unconditioned principle of all that is), thus also, by implication, ignoring the real import of aesthetics as the very access in question.

\section{Conclusion}

Aesthetics, therefore, is not only the experience of positive philosophy, but also a perspective, an access, which is equated with virtue. Here, virtue applies to either everyday ethical comportment or disciplinary engagement with the spirit of the time, its Geist. Nonetheless, the experience and perspective of positive philosophy are certain to be met with resistance from the well-entrenched discipline of thought founded on scientific and logical rationality of negative reason.

In this case, Tritten's position is a significant clarification in terms of acknowledging Schelling's agreement with scientific empiricism (which means the rationality behind negative reason is not entirely blocked from positive philosophy) but only if it first reckons the most important, namely "the aesthesis of the actuality of the world."78 Tritten describes this precognitive actuality as primordial experience which requires"decision and

${ }^{74} \mathrm{Ibid}$.

75 Ibid.

${ }^{76}$ Ibid.

77 Ibid.

${ }^{78}$ Tritten, Beyond Presence, 83. 


\section{SCHELLING AS A TRANSITION THINKER}

deed," as Schelling states, for it to be experienced.. ${ }^{79}$ Pre-cognitive deed is an "experience not of the possible [as in Kant] but of the actual and efficacious." 80 For it to be 'actual' as the aesthesis of the pre-cognitive, experience must be independent of reflective judgment.

Positive philosophy counters negativity by deciding to experience aesthetically what negative reason decides to neglect, that is, the aesthesis of the world. This in turn elevates aesthetics to the level of fundamental concern of freedom, Schelling's 'decision and deed,' but also to that of the ethical (which enhances the aesthetic). But inasmuch as freedom and ethics have been standardized as parts of the larger narrative of reason, normalized thereof in the perception of the public, ${ }^{81}$ the most serious ethical engagement awaits the artist in the cultural realm, and the philosopher in the horizon of educational praxis; altogether, a counter-hegemonic front against the dominance of negative reason in society, culture, and history. This complementary movement of art and philosophy is captured in more pragmatic terms in Gray Kochhar-Lindgren's work on Derrida and Schelling:

Art requires philosophy for its initial thinkability but then, drawing the reflection back into itself, it comes to replace and serve as a stand-in for philosophy. Anyone who wishes to think the Absolute must think art, and therefore it is art that remains. ${ }^{82}$

Art also transforms itself when drawn back to self-reflection by realizing that its self-reflection is already in itself an experience of positive knowledge that is not based on subject-object distinction, the 'unprethinkable' for Schelling. ${ }^{83}$ The experience is also already an active promotion of the actuality of the world, or the free act of giving voice to a nonrepresentational view of history, reason, nature, and reality in general, which consists of the ethical responsibility of both personality types, the philosopher and the artist.

${ }^{79}$ Schelling, System of Transcendental Idealism, 75.

${ }^{80}$ Tritten, Beyond Presence, 81.

${ }^{81}$ Similarly, as Jacques Ranciere would intensify the problem in contemporary time, this normalization of perception is "based on the distribution of spaces, times, and forms of activity that [determine] the manner in which something in common lends itself to participation." See Jacques Ranciere, The Politics of Aesthetics: The Distribution of the Sensible, trans. by Gabriel Rockhill (London and New York: Continuum, 2006), 12.

82 See Gray Kochhar-Lindgren, Philosophy, Art, and the Specters of Jacques Derrida (Amherst, New York: Cambria Press, 2011), 34.

${ }^{83}$ Matthews describes this term as that "which points to that sphere of existence that lies beyond the immanent operations of reflexive thought. See Matthews, Translator's Introduction, 86; see also Schelling, Philosophical Investigations into the Essence of Human Freedom, 29.

(c) 2017 Virgilio A. Rivas

https://www.kritike.org/journal/issue 21/rivas december2017.pdf

ISSN 1908-7330

(c) $)$ BY-NC-ND 
It is in this light that we can now conclude with Schelling: "We are likewise convinced that reason is fully adequate to expose every possible error (in genuinely spiritual matters) and that the inquisitorial demeanor in the judgment of philosophical systems is entirely superfluous." 84 Overall, this answers the question whether Schelling is a transition thinker or systematizer in his own right.

The Graduate School

University of Santo Tomas, Philippines Department of Philosophy and Humanities Polytechnic University of the Philippines

\section{References}

Arendt, Hannah, The Origins of Totalitarianism (San Diego and New York: Harcourt, 1976.)

Beiser, Frederick, German Idealism: The Struggle Against Subjectivism, 1781-1801 (Cambridge, Massachusetts, London and England: 2002).

Bowie, Andrew, Schelling and Modern European Philosophy: An Introduction (London and New York: Routledge, 1993)

Braeckman, Antoon, "From the Work of Art to Absolute Reason: Schelling's Journey Toward Absolute Idealism," in The Review of Metaphysics 57 (March 2004).

Distaso, Leonardo V., The Paradox of Existence: Philosophy and Aesthetics in the Young Schelling (New York: Kluwer Academic Publishers, 2005).

Dodd, James, "Philosophy and Art in Schelling's System des transzendentalen Idealismus," in The Review of Metaphysics 52:1 (1998).

Dobe, Jennifer, "Beauty Reconsidered: freedom and virtue in Schelling's Aesthetics," in Interpreting Schelling: Critical Essays, ed. by Lara Ostaric (Cambridge: Cambridge University Press, 2014).

Frank, Manfred, The Philosophical Foundations of Early German Romanticism, trans. by Elizabeth Millán-Zaibert (Albany, New York: State University of New York, 2004).

Gabriel, Markus, Transcendental Ontology: Essays in German Idealism (London and New York: Continuum, 2011).

Grant, Iain Hamilton, Philosophies of Nature After Schelling (London: Continuum, 2006).

Habermas, Jürgen, "Dialectical Idealism in Transition to Materialism: Schelling's Idea of a Contraction of God and its Consequences for a Philosophy of History," trans. by Nick Midgley and Judith Norman,

${ }^{84}$ Schelling, Philosophical Investigations, 74.

(c) 2017 Virgilio A. Rivas

https://www.kritike.org/journal/issue 21/rivas december2017.pdf

ISSN 1908-7330 


\section{SCHELLING AS A TRANSITION THINKER}

in The New Schelling, ed. by Judith Norman and Alistair Welchman (London and New York: Continuum, 2004), 43-89.

Heidegger, Martin, Schelling's Treatise on The Essence of Human Freedom, trans. by Joan Stambaugh (Athens, Ohio, London: Ohio University Press, 1985).

Being and Time, trans. by John Macquarrie and Edward Robinson (New York: Harper \& Row, Publishers, Inc., 1962).

Hegel, G.W.F., Phenomenology of Spirit, trans. by A. V. Miller (New York: Oxford University Press, 1977).

The Philosophy of History, trans. by J. Sibree (Kitchener, Ontario: Batoche Books, 2001).

The Science of Logic, trans. by George Di Giovanni (New York:

Cambridge University Press, 2010).

Henrich, Dieter, Between Kant and Hegel: Lectures on German Idealism, ed. by David S. Pacini (Cambridge, Massachusetts, London and England: Harvard University Press, 2003).

Jähnig, Dieter, Schelling. Die Kunst in der Philosophie, 2 vols. (Pfüullingen: Neske, 1965).

Kant, Immanuel, Critique of Pure Reason, trans. by Markus Weigelt (New York: Penguin Books, 2007).

Kochhar-Lindgren, Gray, Philosophy, Art, and the Specters of Jacques Derrida (Amherst, New York: Cambria Press, 2011).

Millán-Zaibert, Elizabeth, Friedrich Schlegel and the Emergence of Romantic Philosophy (New York: State University of New York Press, 2007).

Norman, Judith and Alistair Welchman, "Introduction: The New Schelling," in The New Schelling, ed. by Judith Norman and Alistair Welchman (London and New York: Continuum, 2004), 1-12.

Philipps, Wesley, "The Future of Speculation?" Cosmos and History: The Journal of Natural and Social Philosophy 8, 1(2010), 289-303.

Ranciere, Jacques, The Politics of Aesthetics: The Distribution of the Sensible, trans. by Gabriel Rockhill (London and New York: Continuum, 2006).

Schelling, F.W.J., Grundlegung der Positiven Philosophie. Münchener Vorselung WS 1832/33 and SS 1833, ed. by Horst Fuhrmans (Turin: Bottega D' Erasmo, 1972).

Historical-critical Introduction to the Philosophy of Mythology, trans. by Mason Richey and Markus Zisselsberger (Albany, New York: State University of New York Press, 2007).

Idealism and the Endgame of Theory: Three Essays by Schelling, trans. by Thomas Pfau (Albany: State University of New York Press, 1994).

Ideas for a Philosophy of Nature, trans. by Ernol E. Harris and Peter Heath (Cambridge: Cambridge University Press, 1988).

(c) 2017 Virgilio A. Rivas

https://www.kritike.org/journal/issue 21/rivas december2017.pdf

ISSN 1908-7330

(c) ) BY-NC-ND 
On the History of Modern Philosophy, trans. by Andrew Bowie (New York: Cambridge University Press, 1994). Outline of a System of the Philosophy of Nature, trans. by Keith Peterson (New York: State University of New York Press, 2004).

Philosophical Investigations into the Essence of Human Freedom, trans. by Jeff Love and Johannes Schmidt (New York: State University of New York, 2006).

Sämmliche Werke, ed. by K. F. A. Schelling. 14 Vols. (Stuttgart, Cotta: 1856: 1861). System of Transcendental Idealism (1800), trans. by Peter Heath (Charlottesville: University Press of Virginia, 1978).

The Ages of the World (Fragment): From the handwritten remains, third version (c. 1815), trans. by Jason M. Wirth (New York: State University of New York Press, 2000).

The Grounding of Positive Philosophy: The Berlin Lectures, trans. by Bruce Matthews (Albany, New York: State University of New York, 2007).

The Unconditional in Human Knowledge: Four Early Essays (17941796), trans. by Fritz Marti (London: Associated University Press, 1980).

Shaw, Devin Zane, Freedom and Nature in Schelling's Philosophy of Art (Ph.D. Dissertation, Ontario: University of Ottawa, 2009).

Tritten, Tyler, Beyond Presence: The Late F.W.J. Schelling's Criticism of Metaphysics (Boston and Berlin: William de Gruyter, 2012).

Velkley, Richard L., "Realizing Nature in the Self: Schelling on Art and Intellectual Intuition in the System of Transcendental Idealism," in Figuring the Self, Subject, Absolute and Others in German Philosophy, ed. by David E. Klemm and Günter Zöller (Albany, New York: State University of New York Press, 1997), 149-168.

Wirth, Jason M., Conspiracy of Life: Meditations of Schelling and His Time (Albany, New York: State University of New York, 2003).

Žižek, Slavoj, The Indivisible Remainder: On Schelling and Related Matters (London and New York: Verso, 2007).

. The Abyss of Freedom/Ages of the World: An essay by Slavoj Žižek with the text of Schelling's Die Weltarter (second draft 1813) in English translation by Judith Norman (Ann Arbor: The University of Michigan Press, 2004). 